\title{
Jurist-Diction
}

Volume 3 No. 6, November 2020

\section{Pengembalian Kerugian Korban Sebagai Akibat Investasi Ilegal oleh Koperasi}

\author{
Aldika Yafi Raharjo \\ Aldikayafi0@gmail.com \\ Universitas Airlangga
}

\author{
How to cite: \\ Aldika Yafi Raharjo, \\ 'Pengembalian Kerugian \\ Korban Sebagai Akibat \\ Investasi Ilegal Oleh Koperasi' \\ (2020) Vol. 3 No. 6 Jurist- \\ Diction. \\ Histori artikel: \\ Submit 1 September 2020; \\ Diterima 22 September 2020; \\ Diterbitkan 1 November 2020 \\ DOI: \\ 10.20473/jd.v3i6.22952
}

\begin{abstract}
Abstrak
Maraknya tindak pidana yang berkaitan dengan investasi ilegal, telah banyak menimbulkan korban yang jumlah dan kerugiannya sangat besar. Salah satunya adalah praktik investasi ilegal yang dilakukan oleh Pengurus Koperasi Pandawa. Pemidanaan terhadap pelaku ternyata tidak memulihkan kerugian yang diderita oleh korban, oleh karena itu dilakukan penelitian terkait "Pengembalian Kerugian Korban Yang Disebabkan Oleh Investasi Ilegal oleh Koperasi”. Metode penelitian yang digunakan meliputi tipe penelitian yaitu penelitian normatif dengan pendekatan perundang-undangan, pendekatan konseptual serta studi kasus. Hasil penelitian menunjukkan bahwa investasi ilegal merupakan suatu tindak pidana yang memenuhi unsur-unsur perbuatan yang dilarang yang terdapat dalam KUHP, Undang Undang Perbankan, Undang-Undang Nomor 7 Tahun 2014 tentang Perdagangan, Undang-Undang Republik Indonesia Nomor 8 Tahun 2010 Tentang Pencegahan Dan Pemberantasan Tindak Pidana Pencucian Uang serta penanggungjawabannya dalam hal koperasi sebagai pelaku investasi ilegal maka pengurusnya yang harus bertanggungjawab. Mekanisme pengembalian dana melalui peradilan pidana di indonesia terdapat kekosongan hukum yang menyebabkan terjadinya kerugian korban tidak kembali seutuhnya atau tidak kembali sama sekali .berdasarkan penelitian ini dan pemerintah sebagai pelindung dan penjamin hak warga negaranya perlu mengatur cara pengembalian kerugian korban demi kepastian hukum dalam suatu negara. Terkait mekanisme pemulihan kerugian korban oleh karena tidak adanya ketentuan yang secara khusus mengatur maka pengaturannya menggunakan: ketentuan Pasal 98 KUHAP Pasal 14c ayat (1) KUHP Tentang Pedoman Pemulihan Aset melalui Pusat Pemulihan Aset (PPA), Peraturan Pemerintah Nomor 7 Tahun 2018 tentang Pemberian Kompensasi, Restitusi, dan Bantuan Kepada Saksi Korban; UndangUndang Republik Indonesia Nomor 8 Tahun 2010 Tentang Pencegahan Dan Pemberantasan Tindak Pidana Pencucian Uang.

Kata Kunci: Investasi Ilegal; Pengembalian Dana; Tindak Pidana.
\end{abstract}

\section{Pendahuluan}

Pembangunan ekonomi adalah upaya untuk mengubah kehidupan jutaan orang di negara yang berkembang. Pembangunan suatu negara tergantung pada bagaimana negara itu mengelola sumber daya investasinya. Dengan semakin 
banyak pembangunan, semakin besar kebutuhan masyarakat. Dana yang digunakan untuk menggerakkan perekonomian meningkat, oleh karena itu muncul kegiatan menghimpunan dana. menghimpun dana adalah mengumpulkan dana-dana dari masyarakat dan menampungnya dalam bentuk simpanan, giro, tabungan, deposito/ surat berharga lainnya.

Salah satu perusahaan yang bergerak dibidang penghimpunan dana adalah lembaga keuangan. Lembaga keuangan adalah lembaga di bidang jasa keuangan. Metode operasi lembaga keuangan yaitu dengan mengumpulkan dana dari publik dan disalurkan untuk urusan pendanaan yang kemudian akan mendapatkan keuntungan dalam bentuk bunga atau persentase dari proses kegiatan menghimpun dana tersebut. Secara garis besar, lembaga keuangan dapat diklasifikasikan menjadi 3 (tiga) kelompok besar, yaitu :

1. Lembaga Keuangan Bank.

Institusi perbankan adalah Subsistem (lembaga keuangan) yang ada di lembaga keuangan. Menurut hukum perbankan saat ini, Indonesia adalah a menganut konsep sistem perbankan ganda (dual banking sistem). Ini berarti bahwa selain operasi bank tradisional Berdasarkan sistem bunga juga ada bank prinsip syariah. Bank adalah badan usaha yang mengumpulkan dana dari publik dalam bentuk simpanan dan mendistribusikan dana kepada publik dalam bentuk kredit dan bentuk lain untuk meningkatkan kehidupan banyak orang. ${ }^{1}$ Menurut Pasal 5 Undang-Undang Nomor 7 Tahun 1992 jo Undang-Undang Republik Indonesia Nomor 10 Tahun 1998 Tentang Perbankan (Undang-Undang Perbankan) Bank dibagi menjadi tiga kategori, pertama adalah bank sentral yang dikendalikan oleh Bank Indonesia untuk menjaga stabilitas ekonomi rakyat, kedua adalah Bank komersial yang menyediakan jasa dan transaksi keuangan, dan yang lainnya adalah Bank Perkreditan Rakyat yang menerima deposito dalam bentuk deposito tetap.

1 Kasmir, Bank dan Lembaga Keuangan Lainnya (RajaGrafindo Persada 2002).[2] 
2. Lembaga Pembiayaan.

Lembaga pembiayaan adalah entitas bisnis yang terlibat dalam kegiatan pembiayaan Dalam bentuk menyediakan dana atau modal tanpa menarik dana Langsung dari rakyat ${ }^{2}$. Peran lembaga pembiayaan adalah sumber pendanaan alternatif untuk Pertumbuhan ekonomi nasional. ${ }^{3}$

3. Lembaga Keuangan Bukan Bank

Lembaga Keuangan Bukan Bank (LKBB) adalah suatu badan usaha yang yang melakukan kegiatan di bidang keuangan, yang secara langsung atau tidak langsung menghimpun dana terutama dengan jalan mengeluarkan kertas berharga dan menyalurkan dalam masyarakat terutama guna membiayai investasi perusahaan untuk mendapatkan kemakmuran dan keadilan masyarakat ${ }^{4}$.

Peran dari lembaga keuangan non bank adalah:

1. Tingkatkan akses ke layanan keuangan;

2. Mengurangi biaya untuk mendapatkan layanan keuangan;

3. Meningkatkan stabilitas sistem keuangan untuk mendukung pertumbuhan ekonomi dan pengurangan kemiskinan. ${ }^{5}$

Dalam lembaga keuangan non bank terdapat prinsip-prinsip yang harus dipatuhi, yaitu: ${ }^{6}$

1. Jenis pembiayaan pengembangan adalah untuk menyediakan kredit jangka menengah / panjang dan mengurangi modal perusahaan;

2. Jenis investasi ini terutama digunakan sebagai perantara untuk menerbitkan sekuritas dan jaminan, dan bertanggung jawab untuk penjualan sekuritas;

3. Jenis tujuan lain adalah untuk memenuhi kebutuhan masyarakat di area tertentu, seperti memberikan pinjaman bank kepada masyarakat berpenghasilan menengah.

\footnotetext{
${ }^{2}$ Siti Ismijati Jenie. Beberapa Perjanjian Yang Berkenaan Dengan Kegiatan Pembiayaan, (Bahan Penataran Dosen Hukum Perdata Fakultas Hukum UGM).[1].

3 ibid.[2].

${ }^{4}$ Kasmir, Op.Cit.[14].

5 ibid.[15].

6 ibid. [82].
} 
Jenis-jenis lembaga keuangan non bank: ${ }^{7}$

a. Pasar modal

Menurut pasal 1 Undang-Undang Republik Indonesia Nomor 8 Tahun 1995 Tentang Pasar Modal, yang dimaksud dengan pasar modal adalah aktifitas yang terkait dengan penawaran dan permintaan efek (surat berharga), yang berasal dari perusahaan yang terdaftar terkait dengan efek dan lembaga profesional yang terkait dengan efek. Pasar modal juga disebut bursa efek. Di pasar modal, komoditas perdagangan adalah surat berharga. ${ }^{8}$ Jenis sekuritas yang diperdagangkan di pasar modal atau yang biasa disebut dengan instrumen pasar modal, yaitu saham, obligasi. ${ }^{9}$

b. Ansuransi

Ansuransi menurut Undang-Undang Republik Indonesia Nomor 40 Tahun 2014 Tentang Perasuransian adalah perjanjian antara dua pihak atau lebih, di mana perusahaan asuransi mengikatkan diri kepada tertanggung dengan mengumpulkan premi asuransi Untuk memberikan kompensasi atas kerugian pihak ketiga, kerusakan atau keuntungan yang diharapkan atau kewajiban hukum karena alasan berikut: tertanggung dapat terluka karena peristiwa yang tidak pasti, atau membayar sesuai dengan kematian atau kehidupan tertanggung. Jumlah asuransi yang dibayarkan oleh pelanggan disebut premi.

c. Pegadaian

Pegadaian adalah lembaga keuangan yang menyediakan pinjaman kepada pelanggan atas komoditas atau jaminan sekuritas. ${ }^{10}$ Menurut Kasmir pegadaian memiliki ciri-ciri terdapat barang berharga yang diamankan, nilai jumlah pinjaman tergantung pada nilai agunan, barang gadai dapat ditukar. Tujuan utama dari bisnis pegadaian adalah untuk mengatasi / memberikan bantuan sehingga mereka yang membutuhkan dana dapat dengan cepat mendapatkan

\footnotetext{
Kasmir, Op.Cit.[12].

8 ibid.[12].

9 Irham Fahmi, Bank dan Lembaga Keuangan Lainnya Teori dan Aplikasi (Alfabeta 2014).[2].

10 Susilowati, 'Pelaksanaan Gadai Dengan Sistem Syariah Di Perum Pegadaian Semarang',
} (2008) 7 Yuridika.[55]. 
pinjaman dan menghindari riba.

d. Koperasi

Koperasi menurut pasal 1 Undang-Undang Nomor 17 Tahun 2012 Tentang Pengkoperasian adalah badan hukum yang didirikan oleh orang perseorangan atau badan hukum Koperasi, dengan pemisahan kekayaan para anggotanya sebagai modal untuk menjalankan usaha, yang memenuhi aspirasi dan kebutuhan bersama di bidang ekonomi, sosial, dan budaya sesuai dengan nilai dan prinsip Koperasi.

e. Dana Pensiun

Menurut Undang-Undang No. 11 tahun 1992 Tentang Dana Pensiun, dana pensiun adalah badan hukum yang mengelola dan melaksanakan program imbalan pensiun yang dijanjikan. Kegiatan pensiun mengumpulkan dana dari kontribusi, dan selama seseorang masih aktif bekerja, kontribusi tersebut dikurangkan dari pendapatan / gaji karyawan setiap bulan. Jika karyawan tidak lagi bekerja (pensiun), kontribusi akan dikembalikan. Tujuan pemberian pensiun kepada karyawan adalah untuk memberikan penghargaan kepada karyawan yang bekerja di perusahaan, meningkatkan antusiasme mereka, dan meningkatkan citra perusahaan di mata publik dan pemerintah. ${ }^{11}$ Selain itu, dengan dana pensiun, karyawan yang tidak lagi bekerja masih dapat menikmati hasil yang diperoleh saat bekerja untuk perusahaan. ${ }^{12}$ PT Taspen adalah bentuk perusahaan yang mengelola dana pensiun.

Semua bentuk lembaga dalam lembaga keuangan bukan bank ini mempunyai kewenangan menghimpun dana dikarenakan pasal 16 ayat (1) Undang-Undang Republik Indonesia Nomor 10 Tahun 1998 Tentang Perubahan Atas UndangUndang Nomor 7 Tahun 1992 Tentang Perbankan yang berbunyi

1) Setiap pihak yang melakukan kegiatan menghimpun dana dari masyarakat dalam bentuk simpanan wajib terlebih dahulu memperoleh izin usaha sebagai Bank Umum atau Bank Perkreditan Rakyat dari Pimpinan Bank Indonesia, kecuali apabila kegiatan menghimpun dana dari masyarakat dimaksud diatur

\footnotetext{
11 ibid.[80].

12 ibid.[81].
} 
dengan Undang-undang tersendiri.

Dari bunyi undang-undang tersebut menyebutkan bahwa yang menghimpun dana dari masyarakat adalah yang telah memperoleh ijin dari Bank Indonesia sebagai bank. Berarti kalau bukan bank tidak diperbolehkan kecuali diatur dengan undangundang tersendiri misalnya koperasi simpan pinjam, dana pensiun dan asuransi. ${ }^{13}$ Lembaga-lembaga itu sekalipun diperbolehkan menghimpun dana, namun sifatnya spesifik (tidak secara langsung luas meliputi semua lapisan masyarakat) misalnya dana pensiun menghimpun dana bukan dari masyarakat luas, namun hanya dari anggota/peserta program dana pensiun yang sesuai dengan perundangan-undangan dan ketentuan yang berlaku. Demikian pula asuransi, perusahaan asuransi menghimpun dana dengan ketentuan perasuransian yaitu orang yang mengikatkan pada suatu perjanjian pertanggungan untuk obyek tertentu dan peserta asuransi mendapatkan polis asuransi dan membayar premsi yang disepakati. ${ }^{14}$ Dan koperasi simpan pinjam. Koperasi simpan pinjam adalah adalah suatu koperasi yang kegiatan usahanya menghimpun dan menyalurkan dana kepada para anggotanya dengan bunga yang rendah. Sumber permodalan koperasi simpan pinjam berasal dari dua sumber, yaitu dari modal sendiri dan dari modal pinjaman. Modal pinjaman adalah modal yang dihimpun dari para anggota, koperasi lain, dan lembaga keuangan lain seperti Bank. Modal sendiri adalah modal yang berasal dari para anggota koperasi, yaitu berupa simpanan wajib, simpanan pokok, simpanan sukarela, dan hibah. Sudah dijelaskan di depan bahwa menurut pasal 16 Undang-Undang Republik Indonesia Nomor 10 Tahun 1998 Tentang Perubahan Atas Undang-Undang Nomor 7 Tahun 1992 Tentang Perbankan lembaga selain bank boleh menghimpun dana jika diatur oleh peraturan tersendiri. Sementara KSP adalah lembaga koperasi yang diperbolehkan menghimpun dana, sesuai dengan Undang-Undang No 17 Tahun 2012 Tentang Perkoperasian dan Peraturan Menteri Koperasi Dan Usaha Kecil Dan Menengah Republik Indonesia Nomor 09 Tahun 2018 Tentang Penyelenggaraan

\footnotetext{
${ }^{13}$ Oktaviani Suendra, Pertanggungjawaban Pidana Koperasi dalam Tindak Pidana Melakukan Kegiatan Perbankan tanpa Ijin,(2015) 6 Yuridika.[23].

14 ibid.[24].
} 
Dan Pembinaan Perkoperasian yakni menghimpun dana dari para anggota dan atau calon anggota Koperasi dimaksud. Calon anggota sudah boleh untuk dijadikan obyek mengumpulkan dana oleh KSP, tentu si calon anggota itu nantinya setelah memenuhi kriteria tertentu ( 3 bulan) harus diproses menjadi anggota sehingga setelah menjadi anggota KSP mempunyai hak dan kewajiban sebagai anggota koperasi antara lain menghadiri RUPS dan hak-hak untuk mendapatkan Sisa Hasil Usaha (SHU). Itulah azas koperasi yang berazas dari anggota untuk kesejahteraan anggota. Jangan sampai ada calon anggota abadi yang hanya dijadikan obyek penyimpan dana.

Kegiatan menghimpun dana dari masyarakat oleh siapapun pada dasarnya merupakan kegiatan yang perlu diawasi, mengingat dalam kegiatan itu terkait kepentingan masyarakat yang dananya disimpan pada pihak yang menghimpun dana tersebut. ${ }^{15}$ Dengan kata lain masyarakat yang menanamkan dananya di lembaga itu menanggung risiko kalau sewaktu-waktu dana tersebut dapat disalahgunakan oleh lembaga pengimpunan tersebut salah satu contohnya investasi ilegal yaitu dimana lembaga penghimpun dana tersebut menghimpun uang dari masyarakat dan biasanya pengganti dari setoran uang masyarakat tersebut berupa semacam sertifikat/surat tanda penerimaan sebagai investor, depositor dianggap sebagai "Investor". ${ }^{16}$ Mereka akan menarik minat korban dengan imbalan suku bunga yang cukup tinggi dan sering pelaku penghimpun dana masyarakat tersebut berkedok nama-nama yang berkaitan dengan agama bahkan tokoh-tokoh agama sekalipun. Ini menambah-nambah pengkaburan substansi dari istilah penghimpunan dana dari masyarakat yang pada hakekatnya sangat berpotensi merugikan masyarakat itu sendiri karena berpotensi uang hasil penghimpunan dana tersebut dibawa kabur atau dikelola dengan sangat tidak hati-hati dan berujung pada kerugian.

Dalam suatu kegiatan penghimpunan dana oleh koperasi simpan pinjam hal yang di inginkan masyarakat yaitu pertama untuk tidak kehilangan uang yang disebabkan oleh investasi ilegal dan yang kedua kerugian korban yang disebabkan oleh tindak

\footnotetext{
15 ibid.[15].

16 ibid.[16].
} 
pidana dapat kembali lagi. Menurut Kepala Satuan Tugas (Satgas) Waspada Investasi OJK Tongam L Tobing ${ }^{17}$, masih banyak para korban tidak mendapatkan dana kerugian kembali yang di sebabkan oleh investasi ilegal, dan bagi investor yang mendapatkan dana kerugiannya kembali hanya mendapatkan 10\% dari total kerugiannya. Contoh kasus investasi ilegal, kasus Pandawa Grup, Pandawa Grup adalah lembaga keuangan non bank yang bergerak di bidang koperasi simpan pinjam, mereka menawarkan bunga $10 \%$ jika menabung di koperasi tersebut namun itu hanyalah kedok atas penipuan mereka yang menggunakan modus skema piramida yang menyebabkan kerugian korban $\mathrm{Rp}$ 3,9 triliun dan oleh peradilan niaga dinyatakan pailit tetapi aset harta pelaku disita oleh negara atas dasar Putusan Pengadilan Negeri Depok. ${ }^{18}$

Korban tidak mendapatkan kerugiannya kembali dikarenakan sistem peradilan pidana saat ini lebih mementingkan aspek penghukuman pelaku dan bukan kepentingan korban dan itu dapat dilihat dari bagaimana peran korban dalam suatu persidangan yaitu sebagai figuran (saksi) untuk pemain utamanya yaitu pelaku. Peradilan seharusnya bisa menjadi wadah bagi korban untuk mendapatkan kerugian yang disebabkan oleh tindak pidana itu kembali seperti yang dijelaskan dalam pasal 7A ayat (1) Undang-undang No. 31 Tahun 2014 Perubahan atas Undang-Undang Nomor 13 Tahun 2006 Tentang Perlindungan Saksi dan Korban yang menjelaskan bahwa korban tindak pidana berhak atas ganti rugi dari pelaku atas tindak pidana sehingga dapat diartikan bahwa menghukum pelaku saja tidak cukup bagi korban, karena masih ada kerugian korban yang harus dipenuhi.

Dalam sistem peradilan pidana Indonesia terdapat peraturan yang mewajibkan pelaku untuk membayar kerugian yang diderita korban atas hasil tindak pidananya salah satunya adalah pasal 7A ayat (1) Undang-undang No. 31 Tahun 2014 Perubahan atas Undang-Undang Nomor 13 Tahun 2006 Tentang Perlindungan Saksi dan Korban yang menjelaskan bahwa korban tindak pidana berhak atas ganti

\footnotetext{
${ }^{17}$ Athika Rahma, 'terjerumus Investasi Bodong, Bisakah Uang Kembali', (liputan6 ,2015), <https://www.liputan6.com/bisnis/read/4265383/terjerumus-investasi-bodong-bisakah-uang-kembali> diakses pada 29 mei 2020

${ }^{18}$ Hadiarti Trimulyani, 'Perlindungan Hukum Terhadap Korban Kejahatan Investasi Dalam Pelaksanaan Otoritas Jasa Keuangan (Studi Kasus Pandawa Group)’, (2018) 6 Yuridika[23].
} 
rugi dari pelaku atas tindak pidana namun dalam sistem peradilan pidana Indonesia belum ada peraturan yang mengatur mekanisme bagaimana ganti rugi itu sampai ke tangan korban, dalam peradilan pidana terdapat kekosongan hukum dimana harta pelaku yang akan dijadikan ganti rugi akan tidak sampai ke tangan korban dikarenakan tidak ada peraturan jelas tentang pemulihan aset atau harta ganti rugi itu dapat disita oleh Negara. Maka sudah seharusnya pemerintah mulai memikirkan perlindungan hukum kepada para investor yang akan melakukan investasi, maupun itu preventif ataupun represif dari pemerintah, penegak hukum, maupun lembaga yang berkait. Para pihak berwajib harus tidak hanya memikirkan pemidanaan para pelaku tetapi juga membantu para korban yaitu investor yang dirugikan oleh para pelaku usaha ini dengan mengembalikan kerugian mereka.

\section{Konsep investasi Ilegal}

Penghimpunan dana koperasi ini dapat dipersalahgunakan salah satunya dengan investasi ilegal. Investasi ilegal merupakan pergeseran (rekayasa) bahasa dalam istilah penghimpunan dana. ${ }^{19}$ Kalau dicermati bahwa setelah memahami ancaman pidana yang berat atas kegiatan penghimpunan dana sebagaimana dalam pasal 46 Undang-Undang Republik Indonesia Nomor 10 Tahun 1998 Tentang Perubahan Atas Undang-Undang Nomor 7 Tahun 1992 Tentang Perbankan tersebut, para pelaku kejahatan pengimpunan dana mengganti istilah penghimpunan misalnya dengan kegiatan serupa "menabung atau deposito" dengan istilah investasi. ${ }^{20}$ Substansinya sebenarnya sama-sama saja yaitu menghimpun dana dari masyarakat karena dalam prakteknya adalah kegiatan“menarik uang dari masyarakat". ${ }^{21}$

Ciri-Ciri Investasi Ilegal menurut Ketua Satgas Waspada Investasi, Tongam Lumban Tobing: ${ }^{22}$

\footnotetext{
19 ibid.[25].

20 ibid.[26].

21 ibid.[26].

22 Budi Sam, 'Berikut Ciri-Ciri Investasi Bodong, OJK Minta Masyarakat Waspada', (Merdeka,2019)<https://www.merdeka.com/uang/berikut-ciri-ciri-investasi-bodong-ojk-mintamasyarakat-waspada.html $>$ diakses pada 15 juni 2020
} 
1. Tidak ada Dokumentasi Perizinan Usaha/Lembaga

Dalam kegiatan investasi yang dilakukan oleh masyarakat terdapat beberapa badan usaha yang memfasilitasi masyarakat dalam melakukan kegiatan investasi, bagi pelaku usaha dalam mendirikan suatu badan usaha harus mempunyai Surat Izin Usaha Perdagangan (SIUP), dan Tanda Daftar Perusahaan (TDP), tetapi bagi badan usaha yang ingin menghimpun dana dengan modal Surat Izin Usaha Perdagangan (SIUP) dan (TDP) saja tidak cukup. Pendirian suatu badan usaha yang mempunyai wewenang untuk melakukan penghimpunan dana tersebut harus mendapat izin dari otoritas yang berwenang seperti Otoritas Jasa Keuangan (OJK), Bank Indonesia, Bappebti - Kementerian Perdagangan, Kementerian Koperasi dan UKM, dan lain-lainnya. Berdasarkan ketentuan perundang-undangan yang ada. Dalam beberapa kasus, badan usaha yang akan menghimpun dana masyarakat hanya bermodal (SIUP) dan (TDP) dikarenakan banyak investor tidak memiliki pengetahuan tentang izin apa yang harus dilihat sebelum melakukan investasi sehingga membuat para pelaku investasi ilegal degan mudah memperdayai para investor ini dan membuat pengawas yaitu Otoritas Jasa Keuangan (OJK) susah mengawasi para pelaku. Sekarang OJK telah membuat website yang berisikan badan usaha mana yang memiliki izin untuk melakukan aktifitas penghimpunan dana masyarakat sehingga memudahkan para investor. Dokumen perizinan dari beberapa otoritas dilakukan untuk mencegah terjadinya investasi ilegal dan bentuk perlindungan hukum preventif bagi investor.Menawarkan Keuntungan yang Tidak Masuk Akal.

Dalam melakukan investasi, investor berharap mendapatkan keuntungan. Dalam kegiatan investasi ilegal, para pelaku usaha akan membuat suatu gambaran bagi investor bahwa mereka akan mendapat keuntungan walaupun badan usaha itu sedang rugi. Dalam investasi terdapat prinsip (high risk high gain) berdasarkan prinsip ini bahwa investor akan berinvestasi tinggi dengan imbalan yang tinggi tetapi harus siap dengan kerugian yang tinggi, sehingga sangat janggal jika para badan usaha akan menawarkan keuntungan tinggi dengan risiko rugi kecil, bahkan tidak ada risiko rugi sama sekali. 
2. Bergantung pada Rekrutmen Baru

Dalam era bisnis modern terdapat bisnis baru, salah satunya adalah MLM (Multi Level Marketing). MLM adalah strategi pemasaran berjenjang atau berantai, di mana tenaga penjual (sales) tidak hanya mendapatkan kompensasi atas penjualan yang mereka hasilkan, tetapi juga atas hasil penjualan sales lain yang mereka rekrut. ${ }^{23}$ Kelemahan MLM adalah pelaku usaha akan mengeksploitasi sistem perekrutan dengan keuntungan yang dibagikan berupa passive income adalah berasal dari biaya yang digali dan dikumpulkan dari orang baru yang bergabung di kemudian harinya. Mereka yang dibayar umumnya adalah orang yang merekrutnya bersamasama dengan jaringan di atasnya.

\section{Tindak Pidana Yang Terkait Dengan Investasi Ilegal}

Di Indonesia melakukan kegiatan investasi bukan perbuatan yang dilarang, bahkan dilindungi oleh peraturan perundang-undangan yang berlaku di Indonesia, orang mengadakan investasi sebagai bentuk sumber pendapatan suatu perusahaan dengan investor menanamkan suatu jumlah uang kepada produk perusahaan itu dengan mengharapkan keuntungan balik. Tetapi masih ada oknum yang tidak bertanggungjawab yang mengadakan kegiatan investasi yang tidak sesuai peraturan yang berlaku sehingga membuat investasi itu ilegal dan merugikan banyak orang.

Perbuatan melawan hukum yang ada dalam investasi ilegal adalah melakukan suatu penipuan dimana pelaku akan memberi gambaran palsu kepada investor agar investor berinvestasi kepada perusahaan itu dan memberi harapan keuntungan yang tidak masuk akal dengan perusahaan itu mendapat keuntungan dari uang pendaftaran investor baru. ${ }^{24}$ Bukan dari cara yang sah yang diatur dalam UndangUndang Perbankan No.7 tahun 1992 sebagaimana diubah dengan Undang-Undang

\footnotetext{
${ }^{23}$ Moh Bahardin, 'Multi Level Marketing (MLM) Dalam Perspektif Hukum Islam', (2011)13 Yuridika.[65].

${ }^{24}$ Dina ranayanti, 'Bagaimana Ciri-ciri Investasi Bodong? Ini Penjelasan dari OJK'(Detik,2019) <https://finance.detik.com/bursa-dan-valas/d-3225619/bagaimana-ciri-ciri-investasi-bodong-ini-penjelasan-dari-ojk $>$ diakses pada 3 juni 2020.
} 
No 10 tahun 1998 tentang Perbankan yang menjelaskan bahwa menghimpun dana dengan surat berharga dan disertai dengan izin dari badan yang berwenang

Tindakan pidana yang terkait dengan investasi ilegal yang diatur dalam KUHP:

\section{a) Penipuan}

Dalam kamus bahasa Indonesia disebutkan bahwa tipu berarti kecoh, daya cara, perbuatan atau perkataan yang tidak jujur (bohong, palsu, dsb), dengan maksud untuk menyesatkan, mengakali, atau mencari untung. Tindak pidana penipuan atau bedrog diatur dalam buku kedua bab ke XXV undang-undang nomor 1 tahun 1946 tentang peraturan hukum pidana dari Pasal 378-395. Didalam Bab ke XXV tersebut menggunakan kata " penipuan " atau "bedrog”, karena dalam bab berikut diatur sejumlah perbuatan-perbuatan yang ditujukan terhadap harta benda, dimana para pelaku telah melakukan perbuatan-perbuatan yang bersifat menipu atau dipergunakan tipu muslihat. Kaitannya dengan investasi ilegal adalah pelaku usaha Dengan martabat palsu mengaku sebagai pelaku usaha sukses, dengan tipu muslihat pelaku usaha mengaku akan memberikan keuntungan pada investor.

b) Penggelapan uang

Pengertian tindak pidana penggelapan diatur dalam Pasal 372 KUHP. Pasal 372 KUHP Menurut R. Soesilo Penggelapan uang merupakan kejahatan yang memiliki beberapa unsur yang sama dengan pencurian dalam pasal 362 KUHP Perbedaannya adalah bahwa barang-barang yang dimiliki oleh pencurian tidak ada di tangan pencuri, ketika pencuri melakukan tindak pidana sedangkan pada penggelapan waktu dimilikinya barang itu sudah ada di tangan si pelaku tidak dengan jalan kejahatan tetapi dengan cara yang legal. Dalam investasi ilegal, unsur mendapatkan harta benda secarah sah bukan karena kejahatan yaitu dengan menghimpun dana masyarakat serta memiliki izin dari OJK untuk melakukan kegiatan menghimpun dana namun investor tidak mendapatkan keuntungan dari investasi atas produk yang diinvestasikan itu tetapi dari suatu tindak pidana, sehingga dapat diartikan walaupun mempunyai izin yang sah dari OJK pelaku usaha masih bisa dapat melakukan tindak pidana investasi ilegal. 
c) Pencucian Uang

Pencucian uang adalah tindakan seseorang yang menyamarkan dan/ atau menyembunyikan sumber uang yang diperoleh dari hasil kriminal dengan memasukkan uang ke dalam sistem bisnis yang sah. Dalam investasi ilegal, para pelaku usaha akan mendapat keuntungan dari suatu tindak pidana kemudian akan "mencuci" uang hasil tindak pidana tersebut ke bisnis investasi tersebut seakanakan pelaku usaha tersebut mendapat keuntungan dari bisnis investasi tersebut

d) Permainan Uang (Money Game)

Penjualan piramida adalah bentuk penipuan Promotor melakukan apa yang mereka sebut "investasi" Atau "Perdagangan (komersial)" untuk tujuan memperkayakan diri diri. Kekayaan diperoleh melalui uang pembayaran awal anggota investor baru yang melalui sistem rekrutmen dan sehingga membentuk piramida. Skema piramida juga diartikan sebagai suatu sistem Investasi palsu, membayar peserta lama dengan uang dari peserta baru bukan dari keuntungan perusahaan. Skema piramida merupakan modus operandi yang sering digunakan dalam investasi ilegal sehingga banyak yang menyamakan kedua tindak pidana ini. Namun skema piramida adalah salah satu modus operandi sama dengan MLM dan money game.

e) Tidak Memiliki Izin Menghimpun Dana dalam koperasi simpan pinjam

Dalam Undang-Undang No 17 Tahun 2012 Tentang Perkoperasian hanya mengatur sanksi administratif dan bukan sanksi pidana Sehingga apabila suatu koperasi penghimpunan dana tanpa izin, undang-undang Perkoperasian hanya mampu untuk memberikan sanksi administrasi yaitu berupa pencabutan ijin dari koperasi tersebut namun tidak ada pemidanaan lebih lanjut yang diatur.

Oleh karena itu lembaga penghimpun dana ditetapkan harus sebagai bank menurut pasal 57 Undang-Undang Republik Indonesia Nomor 10 Tahun 1998 Tentang Perubahan Atas Undang-Undang Nomor 7 Tahun 1992 Tentang Perbankan karena lembaga perbankan diawasi secara ketat otoritas jasa keuangan melalui pengawasan bank secara langsung (on-site supervision) terdiri dari pemeriksaan umum dan pemeriksaan khusus dengan tujuan untuk mendapatkan gambaran 
keadaan keuangan bank dan untuk memantau tingkat kepatuhan bank terhadap peraturan yang berlaku, serta untuk mengetahui apakah terdapat praktik-praktik tidak sehat yang membahayakan kelangsungan usaha bank; dan pengawasan tidak langsung (off-site supervision) yaitu pengawasan melalui alat pemantauan seperti laporan berkala yang disampaikan bank, laporan hasil pemeriksaan, dan informasi lainnya. Dengan begitu dapat dipertanggungjawabkan seperti halnya dengan bank yaitu dengan pasal 46 Undang-Undang Republik Indonesia Nomor 10 Tahun 1998 Tentang Perubahan Atas Undang-Undang Nomor 7 Tahun 1992 Tentang Perbankan.

\section{Pertanggungjawaban Koperasi Atas Investasi Ilegal}

Dalam hal perbuatan hukum, merupakan kejahatan atau suatu tindak pidana apabila actus reus tindak pidana tersebut dilakukan oleh manusia sebagai pelaku tindak pidana itu (pengurus). ${ }^{25}$ Berdasarkan pemahaman tersebut, maka tidak seharusnya sistem pertanggungjawaban pidana yang dianut adalah bahwa hanya korporasi yang harus memikul pertanggungjawaban pidana, sedangkan manusia pelakunya dibebaskan.

Sama halnya dengan koperasi, pengurus koperasi tidak boleh dibebaskan begitu saja ketika telah melakukan tindak pidana.Dalam Teori Badan Hukum, selain manusia, badan hukum juga dipandang sebagai subyek hukum. ${ }^{26}$ Hal inilah yang menjadi dasar pembenar dari pertanggungjawaban pidana oleh koperasi. Koperasi sebagai badan hukum dapat dilihat dalam penjabaran Pasal 1 ayat (1) Undang-Undang Nomor 17 Tahun 2012 Tentang koperasi.

Mekanisme Pengembalian Dana Kerugian Investor Yang Disebabkan Oleh Tindak Pidana Yang Terkait Dengan Investasi Ilegal

- Pasal 98 KUHAP

Jika ganti rugi tidak dimasukan dalam petitum, korban dapat meminta kepada hakim penggabungan perkara ganti kerugian yang dijelaskan dalam pasal

\footnotetext{
25 Oktaviani Suendra, Op.Cit.[35].

${ }^{26}$ Oktaviani Suendra, Op.Cit.[36].
} 
98 KUHAP "jika suatu perbuatan yang menjadi dasar dakwaan di dalam suatu pemeriksaan perkara pidana oleh pengadilan negeri menimbulkan kerugian bagi orang lain, maka hakim ketua sidang atas permintaan orang itu dapat menetapkan untuk menggabungkan perkara gugatan ganti kerugian kepada perkara pidana itu" korban dapat mengajukan Penggabungan Perkara Ganti Kerugian kepada hakim sebelum penuntut umum mengajukan tuntutan pidana, dengan begitu hakim akan memeriksa seberapa besar ganti rugi yang akan didapatkan oleh korban

- Peraturan Jaksa Agung No. 27 Tahun 2014 Jo. Peraturan Jaksa Agung No. 9 Tahun 2019 Tentang Pedoman Pemulihan Aset

Penuntutan ganti rugi juga bisa dilakukan atas inisiatif oleh JPU itu sendiri Berdasarkan Peraturan Jaksa Agung No. 27 Tahun 2014 Jo. Peraturan Jaksa Agung No. 9 Tahun 2019 Tentang Pedoman Pemulihan Aset yang menjelaskan jaksa akan mengembalikan harta sita kepada korban atau pemilik yang berhak melalui Pusat Pemulihan Aset (PPA). Pusat Pemulihan Aset adalah peran kejaksaan dalam memastikan bahwa pemulihan aset di indonesia bekerja secara optimal, tidak hanya pemulihan aset ke korban tetapi juga ke negara yang menjadi tanggung jawab PPA. ${ }^{27}$ - Pasal 14c Ayat (1) KUHP

Hakim juga memiliki wewenang dalam pengembalian dana investor dengan hakim meminta kepada terpidana untuk mengembalikan kerugian korban yang ditimbulkan oleh tindak pidana yang dilakukan oleh terpidana yang disampaikan saat pembacaan putusan yang diatur dalam Pasal 14c Ayat (1) KUHP.

- Peraturan Pemerintah Nomor 7 Tahun 2018 tentang Pemberian Kompensasi, Restitusi, dan Bantuan Kepada Saksi Korban.

LPSK dapat mengajukan restitusi untuk korban, restitusi adalah ganti kerugian yang diberikan kepada Korban atau Keluarganya oleh pelaku atau pihak ketiga. Dalam pasal 19 Peraturan Pemerintah Nomor 7 Tahun 2018 tentang Pemberian Kompensasi, Restitusi, dan Bantuan Kepada Saksi Korban, korban tindak pidana berhak memperoleh Restitusi berupa ganti kerugian atas kehilangan kekayaan

${ }^{27}$ Mashuril Anwar, 'Implementasi Peraturan Jaksa Agung No. 028/A/Ja/10/2014 Tentang Pedoman Penanganan Perkara Pidana Korupsi Dengan Subjek Hukum’ (2015) 12 Yuridika.[22]. 
atau penghasilan. LPSK akan mengajukan restitusi baik sebelum, maupun sesudah putusan pengadilan berkekuatan hukum tetap.

- Undang-Undang Republik Indonesia Nomor 8 Tahun 2010 Tentang Pencegahan Dan Pemberantasan Tindak Pidana Pencucian Uang

Dalam TPPU terdapat mekanisme pengembaliankerugian korbanjika kerugian tersebut disebabkan oleh tindak pidana pencucian uang yang dilakukan oleh Pusat Pelaporan dan Analisis Transaksi Keuangan (PPATK) yang merupakan lembaga sentral (focal point) yang mengkoordinasikan pelaksanaan upaya pencegahan dan pemberantasan tindak pidana pencucian uang di Indonesia. Dalam hal yang diduga sebagai pelaku tindak pidana tidak ditemukan oleh Penyidik dalam waktu tiga puluh hari, maka Penyidik dapat mengajukan permohonan kepada Pengadilan Negeri untuk memutuskan harta kekayaan tersebut sebagai aset negara atau dikembalikan kepada yang berhak berdasarkanPasal 67 ayat (2) Undang-Undang Republik Indonesia Nomor 8 Tahun 2010 Tentang Pencegahan Dan Pemberantasan Tindak Pidana Pencucian Uang.

\section{Pengembalian Kerugian Korban Dalam Peradilan Pidana}

Dalam lembaga keuangan terdapat badan pengawas bernama Otoritas Jasa Keuangan yang selanjutnya disingkat OJK adalah lembaga Negara yang dibentuk berdasarkan Undang-undang Nomor 21 Tahun 2011 yang berfungsi menyelenggarakan sistem pengaturan dan pengawasan yang terintegrasi terhadap keseluruhan kegiatan di dalam sektor jasa keuangan baik di sektor perbankan, pasar modal, dan sektor jasa keuangan non-bank. Dalam kasus investasi ilegal, OJK dapat bertindak jika ada pengaduan dari investor yang dirugikan sesuai kewenangan mereka yang diatur dalam Pasal 29 Undang-Undang Nomor 21 Tahun 2011 tentang Otoritas Jasa Keuangan, OJK melakukan pelayanan pengaduan konsumen. OJK akan menindaklanjuti aduan investor dengan mengajukan gugatan ke peradilan sebagai bentuk pembelaan hukum investor yang merupakan wewenang OJK yang diatur dalam Undang-Undang Nomor 21 Tahun 2011 tentang Otoritas Jasa Keuangan pasal 30 ayat (1). OJK akan berkoordinasi dengan kepolisian dalam 
melakukan penyidikan untuk mengetahui legalitas perusahaan dalam melakukan kegiatan investasi sebelum mengajukan gugatan ke peradilan dan mengirimkan hasil penyidikan ke jaksa yang diatur dalam pasal 49 Undang-Undang Nomor 21 Tahun 2011 tentang Otoritas Jasa Keuangan. Setelah semua bukti semua terkumpul, penyidik akan mengirim berkas perkara ke Jaksa Penuntut Umum (JPU) yang mempunyai wewenang yang diatur dalam pasal 14 KUHAP. Dalam pasal ini dijelaskan bahwa JPU setelah menerima berkas penyidikan dari penyidik, mereka akan membuat surat dakwaan. Dalam surat dakwaan harus terdapat identitas para subjek dan uraian secara jelas tentang tindak pidana yang dilakukan sesuai pasal 143 ayat (2) KUHAP. Dalam surat dakwaan juga terdapat petitum, petitum adalah tuntutan apa saja yang diinginkan oleh penggugat. Dalam kasus ini penggugat adalah JPU dan dia dapat menuntut ganti rugi sebagai tuntutan JPU kepada terdakwa seperti yang diatur dalam pasal 101 KUHAP. Setelah salah satu mekanisme diatas telah dilakukan, maka langkah selanjutnya untuk mengambil harta ganti rugi tersebut yaitu dengan sita umum. Dalam pidana ekonomi, sita umum tidak hanya dilaksanakan dengan tujuan pembuktian yang akan dilakukan oleh jaksa penuntut umum yang akhirnya akan digunakan untuk meyakinkan hakim bahwa terdakwa bersalah. ${ }^{28}$ Namun juga sebagai bentuk ganti rugi korban setelah ada putusan dari hakim. Sita umum diatur dalam pasal 1 angka 16 KUHAP.

Dalam Peraturan Pemerintah Republik Indonesia Nomor 92 Tahun 2015 Tentang Perubahan Kedua Atas Peraturan Pemerintah Nomor 27 Tahun 1983 Tentang Pelaksanaan Kitab Undang-Undang Hukum Acara Pidana ganti rugi diatur dalam pasal 7 sampai dengan pasal 11 namun dari pasal itu tidak dijelaskan tentang bagaimana mekanisme pengembalian kerugian korban, salah satu yang tidak diatur adalah bagaimana jika uang korban sudah dipakai dan dipergunakan oleh pelaku. ${ }^{29}$ Dalam kasus investasi ilegal, investor akan berinvestasi dalam bentuk uang untuk mendapat keuntungan dari uang yang diinvestasikan sehingga menjadi polemik jika

\footnotetext{
${ }^{28}$ Usman Arifin, 'Asset Recovery Korban Tindak Pidana Penipuan dan Penggelapan Dalam Kaitannya Dengan perlindungan Korban Kejahatan’ (2016) 9 Yuridika.[19].

29 ibid.[12].
} 
uang investor dipergunakan oleh pelaku dalam tindak kejahatan sehingga korban tidak akan mendapatkan kerugiannya kembali seutuhnya, atau uang korban diubah oleh pelaku ke dalam bentuk barang kemudian disita dan harus dikembalikan ke korban sehingga harus dijual dulu tetapi tidak ada mekanisme cara penjualan barang tersebut dan siapa yang berwenang untuk menjual barang tersebut. ${ }^{30}$ Jaksa hanya berwenang untuk menjual barang sitaan apabila Hakim memutuskan barang tersebut dirampas untuk negara dan hasilnya harus disetorkan ke dalam kas negara bukan untuk pemulihan aset korban menurut Pasal 82 Ayat (1) Peraturan Menteri Keuangan (PMK) No. 27/PMK.06/2016 Tahun 2016 tentang Petunjuk Pelaksanaan Lelang.

Dalam peradilan pidana tidak ada mekanisme pencocokan barang sita dengan total kerugian korban, yang memastikan kerugian korban sama dengan harta yang disita. ${ }^{31}$ Situasi ini akan membuat pengembalian dana korban investasi ilegal lebih sulit, dikarenakan salah satu karateristik investasi ilegal yaitu memiliki korban yang banyak seperti kasus koperasi pandawa yang memiliki 5.459 korban sehingga jika harta sita lebih sedikit jika dibandingkan dengan kerugian korban maka tidak jelas siapa yang akan mendapatkan harta itu duluan mengingat kerugian korban investasi ilegal adalah uang sehingga tidak bisa dibuktikan dengan hak milik.

Dalam investasi ilegal, hakim menggunakan pasal 39 KUHP dan 46 KUHAP sebagai dasar dalam penyitaan aset pelaku, namun dua pasal tersebut juga dapat menjadi batu sandungan bagi korban investasi ilegal dalam mendapatkan kerugiannya kembali karena pasal tersebut menjadi dasar hakim untuk merampas hasil sita aset pelaku untuk negara. Dijelaskan bahwa aset pelaku yang disita oleh peradilan dapat diserahkan kepada pemerintah. Hanya berlaku pada barang sita dari tindak pidana kejahatan. Seperti yang sudah dijelaskan sebelumnya bahwa investasi ilegal terdapat unsur-unsur tindak pidana yang bersifat kejahatan seperti penipuan, tindak pidana pencucian uang. kesusahan dalam mendapatkan pengembalian kerugian investor.

${ }^{30}$ Heri Jerman, 'Pemulihan Aset Hasil Kejahatan Sebagai Bentuk Perlindungan Hukum Terhadap Korban Kejahatan’ (2017) 13 Yuridika.[12].

${ }^{31}$ Heri Jerman, Op.Cit.[14]. 
Hakim akan menyita aset pelaku untuk negara jika korban tidak meminta ganti rugi dengan mekanisme dijelaskan sebelumnya atau korban tidak dapat membuktikan jika barang yang disita miliknya. Jaksa Penuntut Umum dapat memohon kasasi dengan alasan judex factie kesalahan pengembalian barang bukti tersebut ke negara dan bukan ke korban dengan dengan sesuai yang diatur dalam pasal 253 KUHAP. Disini jaksa akan membuktikan bahwa barang bukti tersebut adalah milik korban namun akan susah bagi korban investasi ilegal karena kerugian yang diderita korban investasi ilegal dalam bentuk uang sehingga akan susah membuktikan dengan hak milik.

\section{Kesimpulan}

Investasi ilegal dalam koperasi yang perbuatan melawan hukumnya memenuhi unsur tindak pidana yang diatur dalam beberapa undang-undang yang ada di Indonesia seperti KUHP, Undang-Undang Republik Indonesia Nomor 7 tahun 2014 tentang Perdagangan, Undang-Undang Republik Indonesia Nomor 8 Tahun 2010 Tentang Pencegahan Dan Pemberantasan Tindak Pidana Pencucian Uang, Undang-Undang Republik Indonesia Nomor 10 Tahun 1998 Tentang Perubahan Atas Undang-Undang Nomor 7 Tahun 1992 Tentang Perbankan. Sementara itu pertanggungjawaban pidana yang berkaitan dengan koperasi hanya dibebankan kepada pengurus/ pimpinan koperasi yang memberikan perintah sehingga pertanggungjawabannya hanya diberikan kepada pribadi masing-masing.

Indonesia memiliki peraturan yang mengatur mekanisme pengembalian dana korban yang disebabkan oleh tindak pidana melalui peradilan pidana dalam Undang Undang No. 8 Tahun 1981 Tentang Kitab Hukum Acara Pidana, yaitu dengan dimasukan dalam surat dakwaan, penggabungan perkara ganti kerugian, inisiatif dari hakim itu sendiri serta dalam Peraturan Jaksa Agung No. 27 Tahun 2014 Jo. Peraturan Jaksa Agung No. 9 Tahun 2019 Tentang Pedoman Pemulihan Aset melalui Pusat Pemulihan Aset (PPA), Peraturan Pemerintah Nomor 7 Tahun 2018 tentang Pemberian Kompensasi, Restitusi, dan Bantuan Kepada Saksi Korban Undang-Undang Republik Indonesia Nomor 8 Tahun 2010 Tentang Pencegahan 
Dan Pemberantasan Tindak Pidana Pencucian Uang namun terdapat kekosongan hukum dalam hukum acara pidana dimana para korban tidak mendapat sepenuhnya ganti rugi atau tidak sama sekali.

\section{Daftar Bacaan}

\section{Buku}

Kasmir, Bank dan Lembaga Keuangan Lainnya (RajaGrafindo Persada 2002).

Irham Fahmi, Bank dan Lembaga Keuangan Lainnya Teori dan Aplikasi, (Alfabeta 2014).

Arief Gosita, KUHAP Dan Pengaturan Ganti Rugi Pihak Korban (Pustaka Sinar Harapan 1987).

Chairul Huda, Dari Tindak Pidana Tanpa Kesalahan Menuju Kepada Tiada Pertanggung jawab Pidana Tanpa Kesalahan, Cetakan ke-2, (Kencana 2006).

Murti Lestari, Bank dan Lembaga Keuangan Nonbank (Universitas Terbuka 2015).

\section{Jurnal}

Heri Jerman, 'Pemulihan Aset Hasil Kejahatan Sebagai Bentuk Perlindungan Hukum Terhadap Korban Kejahatan' (2017) Universitas 17 Agustus 1945 Surabaya.

Fauzy Marabesy, ' restitusi bagi korban tindak pidana'(2015) universitas Indonesia.

Oktaviani Suendra, 'Pertanggungjawaban Pidana Koperasi dalam Tindak Pidana Melakukan Kegiatan Perbankan tanpa Ijin' (2015) Universitas Udayana Denpasar.

\section{Laman}

Luhung Sapto, "Kronologi penipuan berkedok investasi oleh pandawa group", https://merahputih.com/post/read/kronologi-penipuan-berkedok-investasioleh-pandawa-group diakses pada 23 mei 2020.

Athika Rahma, 'terjerumus Investasi Bodong, Bisakah Uang Kembali', (Liputan6,2015)<https://www.liputan6.com/bisnis/read/4265383/ terjerumus-investasi-bodong-bisakah-uang-kembali> diakses pada 29 mei 2020. 
Dina ranayanti, 'Bagaimana Ciri-ciri Investasi Bodong? Ini Penjelasan dari OJK', (Detik,2019)<)https://finance.detik.com/bursa-dan-valas/d-3225619/ bagaimana-ciri-ciri-investasi-bodong-ini-penjelasan-dari-ojk $>$ diakses pada 3 juni 2020.

Budi Sam, 'Berikut Ciri-Ciri Investasi Bodong, OJK Minta Masyarakat Waspada', (Merdeka,2019) <https://www.merdeka.com/uang/berikut-ciri-ciri-investasibodong-ojk-minta-masyarakat-waspada.html> diakses pada 15 juni 2020. 
1978

Aldika Yafi: Pengembalian Kerugian Korban

--halaman ini sengaja dibiarkan kosong-- 